\title{
Job Satisfaction, Organizational Commitment, Organizational Citizenship Be- havior (OCB), and Performance of the Vocational High School Teachers
}

\author{
Deddy Rahman Hidayat \\ Master Program of Education Management, Universitas Lambung Mangkurat, Banjarmasin 70123, \\ Indonesia
}

Article history:

Submission November 2019

Revised July 2020

Accepted August 2020

${ }^{*}$ Corresponding author:

E-mail:de78erhidayat@gmail.com

\begin{abstract}
The purpose of this study is to analyze and describe the Effect of Job Satisfaction, Organizational Commitment, and Organizational Citizenship Behavior (OCB) on Teacher Performance. The study uses an explanatory survey method with a quantitative approach, a sample size of 142 taken randomly from 221 teachers in all State Vocational High School of Banjar Regency. The questionnaire was tested for validity and reliability, and the data were analyzed descriptively using path analysis. The results showed that (1) there was a direct relationship between job satisfaction, organizational commitment, OCB, and teacher performance; (2) there is an indirect relationship between job satisfaction and performance through teacher OCB; as well as between organizational commitment and performance through OCB.
\end{abstract}

Keywords: Job satisfaction, organizational commitment, organizational citizenship behavior (OCB), teacher performance

\section{Introduction}

The development of vocational education in line with graduate competencies, the Indonesia Ministry of Education and Culture (Kemdikbud) adjusts and develops vocational education curricula at the secondary level. With the use of a supply-driven approach, changing and adjusting to demand-driven, the World of Business and Industry (DUDI) is actively involved in the Vocational High School education (Effendy, 2016). According to Suparlan (2006), the quality of Vocational High School graduates is influenced by several factors, including teachers' performance. In case their performance is poor, the quality of graduate decreases. A teacher with high productivity needs a positive attitude towards work, and this involves being responsible, working earnestly, maintaining the quality of work, and high dedication.

Hanif (2004) stated that the teaching profession has roles and responsibilities, not only in the classroom but also in the school organizations and management. Curriculum changes according to the era and innovations or renewal of education, and the teacher needs to work with parents and serve the community (community services). Therefore, teaching performance has been considered to be important. Performance is closely related to the achievements of a person or institution in carrying out tasks, and therefore, relates to organizational goals. In case organizational goals are achieved appropriately, the performance will be positive (Mangkunegara, 2000).

The refinement and improvement of teacher performance are based on the assessment of the system, promotion, training, and allowances. (Kompri, 2016). While, according to Hanif (2004), teacher performance is significantly influenced by various factors, including stress, work motivation, and job satisfaction, students in the class, income, work experience,

How to cite:

Hidayat, D. R. (2020). Job satisfaction, organizational commitment, Organizational Citizenship Behavior (OCB), and performance of the vocational high school teachers. Journal of K6, Education, and Management, 3 (1), 32 - 39. doi: 10.11594/jk6em.03.01.05 
workload, environment, gender, public-private schools, and status.

Teacher performance in Private Schools in Pakistan established that job satisfaction and financial support significantly affected the effectiveness of teaching. The higher the level of teacher satisfaction and financial ability, the higher the level of performance (Astawa, 2009). According to Chamundeswari (2013) found significant differences between job satisfaction, position, and organizational commitment of 132 teachers. From the same study, there was a relationship between job satisfaction and performance. Another study stated that teacher job satisfaction has a significant impact on teacher quality and productivity to realize national education goals (Suriansyah, 2018).

According to Robbins et al. (2008) define job satisfaction as a positive feeling about work resulting from assessing and evaluating its characteristics. Arnold and Randall (2005) also defines it as a pleasant or positive emotional condition resulting from assessment or work experience. This concept generally refers to various aspects of work affecting the level of satisfaction, including attitudes towards wages, working conditions, coworkers and bosses, career prospects, and intrinsic aspects of the job itself.

According to Renyut et al. (2017), job satisfaction is a component of organizational commitment in a pleasant condition for someone as a result of conformity between self-values and work. From Robert and Kinicki (2004), organizational commitment is a reflection of an employee to recognize and bind the organizational goals. This is a crucial work attitude since committed employees are expected to show their abilities to work harder in achieving organizational goals and have a greater desire to continue working in a company. Organizational commitment is employee loyalty reflected in high involvement to achieve organizational goals (Priansa, 2014). Additionallty, Luthans (2011) defines organizational commitment as; (a) a strong desire to remain a member of a particular organization, (b) an urge to put efforts at a high level on behalf of the organization, and (c) definite confidence in acceptance of the organization's values and goals. Sopiah (2008) explains that organizational commitment is a unitary attitude of employees. It is the willingness of individuals to strive together with three principal characteristics, including affective, continuance, and normative commitment. High performance of human resources encourages the emergence of OCB, which is the positive behavior beyond the standard of the company (Robert \& Kinicki 2004).

According to Organ and Ryan (2006), a person's performance in an organization has an overall impact that results in behavior. organizational citizenship behavior (OCB) is an individual contribution where the work activities exceed the standard. The dimensions of OCB play a vital role in the organization. Although there is no award for achieving OCB, the performance is better (Luthans, 2006). However, Robbins and Judge (2009) stated that OCB is a choice but not a formal work obligation for a teacher, though it supports the organization effectively. The teacher's OCB is said to be extrarole behavior outside the job description, not because of reward but intrinsic awareness factors.

Aslamiah (2015) stated that teacher performance is becoming a concern for everyone, and as a result, many positive and negative views on teachers influence their professionalism. Performance needs be a priority for improvement by all stakeholders, including the school principals. Generally, the school head has a significant and strategic role in spearheading and improving teacher performance. This can be achieved through leadership that creates job satisfaction, organizational commitment, and form OCB. For this reason, this study examines the performance of teachers and the variables that are likely to influence the principal's transformational leadership, job satisfaction, organizational commitment, and OCB. The study aims to discuss the influence of teacher performance in providing services, focusing on aspects such as job satisfaction, organizational commitment, and OCB teacher performance.

\section{Material and Methods}

This study uses an explanatory survey method with a quantitative approach through correlation and path analysis. Importantly, the analysis is used in testing the influence shown 
by the correlation coefficient between the variables of job satisfaction (X1), organizational commitment (X2) with OCB as an intermediate variable $(\mathrm{Z})$ on teacher performance $(\mathrm{Y})$. Correlational research aims to find relationships between two or more variables (Arikunto, 2006). Based on quantitative characteristics, this study was conducted by collecting data in the form of numbers, then processed and analyzed to obtain scientific research information based on (Sugiyono, 2012).

\section{Sample of study}

In this study, the population was 221 State Vocational High School teachers in Banjar Regency. The sample involved 142 teachers from six schools selected by stratified proportional random sampling with the status of Civil Servants with a minimum service period of three years. This includes individuals with a Teacher and Education Staff Number. There were instructors to be included by the government in the Teacher Performance
Assessment, assuming that they understand job satisfaction, organizational commitment, and performance, and have a supportive attitude towards the organization.

\section{Data collection}

The research instrument is a questionnaire used to collect the data on Job Satisfaction, Organizational Commitment, and OCB for teachers. Also, the performance of the State Vocational High School teacher in Banjar District was taken from the recapitulation data of the Teacher Performance Assessment at the Office of Education and Culture of South Kalimantan Province. The lattice used in compiling the research instruments is developed based on indicators determined from each variable on the study of theory and operational definitions. The data were collected through a four scale model questionnaire by choosing the best answers that fit the actual conditions. The research model is shown in Figure 1.

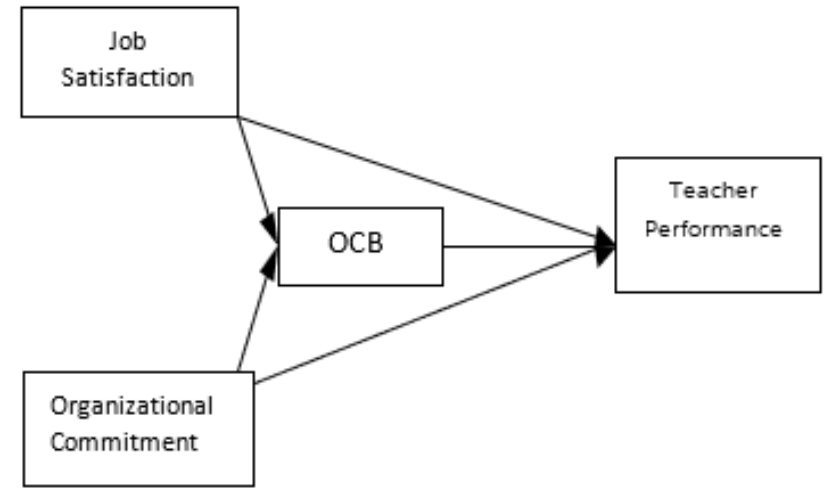

Figure 1. The research model

The research model using path analysis to answer the seven research hypotheses, including:

H1: There is a positive and significant relationship between job satisfaction and teacher performance.

$\mathrm{H} 2$ : There is a positive and significant relationship between organizational commitment and teacher performance.

H3: There is a positive and significant relationship between OCB and teacher performance.

H4: There is a positive and significant relationship between job satisfaction and OCB.
H5: There is a positive and significant relationship between organizational commitment and OCB.

H6: There is a relationship between job satisfaction and teacher performance through OCB.

H7: There is a relationship between Organizational commitment and teacher performance through OCB.

\section{Data analysis}

The score in this study was determined using a Likert scale, which is a more systematic way of providing an index score (Sugiyono, 
2012). Respondents were asked to show their preferences by choosing a category rating system, ranging from strongly agree, agree, neutral, disagree, and strongly disagree. The scoring is carried out by assigning the highest value on the "strongly agree" and the lowest on the "strongly disagree."

This research uses the path analysis explanatory survey method with a quantitative approach through correlation and path analysis. Essentially, the analysis is used in testing the effect shown by the correlation coefficient between job satisfaction, organizational commitment, and OCB as intermediate variables on teacher performance.

\section{Results and Discussion}

The results of the questionnaire validity test of job satisfaction, organizational commitment, and OCB stated that all items of questions and statements were valid since the value of $r$ count was above the $r_{\text {table. }}$ In the Cronbach alpha coefficient reliability test, these results are greater than 0.60 , which means the three questionnaires are reliable.

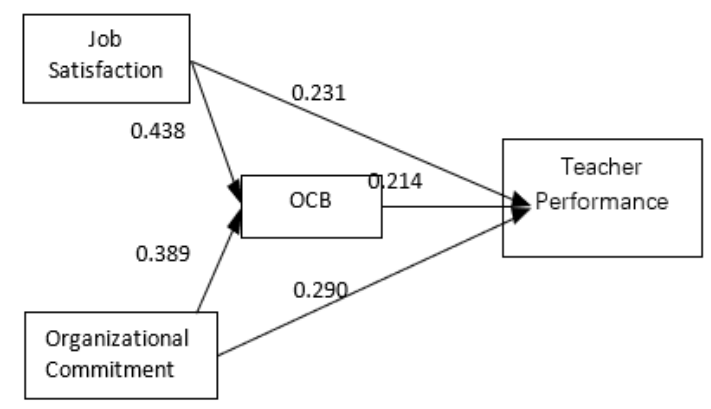

Figure 2. Relationship between all variables

Table 1. Mean, Standard Deviation, and Research Variable Stage

\begin{tabular}{lccc}
\hline \multirow{2}{*}{ Variable } & Mean & Standard Deviation & Category \\
\cline { 2 - 4 } & & & \\
\hline Job satisfaction & 71.078 & 4.758 & Very high \\
\hline Organizational Commitment & 75.472 & 5.086 & Very high \\
\hline OCB & 67.760 & 3.108 & High \\
\hline Teacher Performance & 48.458 & 2.259 & Very high \\
\hline
\end{tabular}

Table 2. Summary of path analysis results

Sub Structural 1: Job Satisfaction, Organizational Commitment toward OCB

\begin{tabular}{lcccc}
\hline Variable & $\begin{array}{c}\text { Path } \\
\text { coefficient }\end{array}$ & $\boldsymbol{T}$ & Sig & $\boldsymbol{R}^{2}$ \\
\cline { 1 - 3 } Job satisfaction & 0.438 & 6.509 & 0.000 & \\
\cline { 1 - 4 } $\begin{array}{l}\text { Organizational } \\
\text { Commitment }\end{array}$ & 0.389 & 5.780 & 0.000 & 0.496 \\
\hline
\end{tabular}


Table 3. Summary of Path Analysis Results

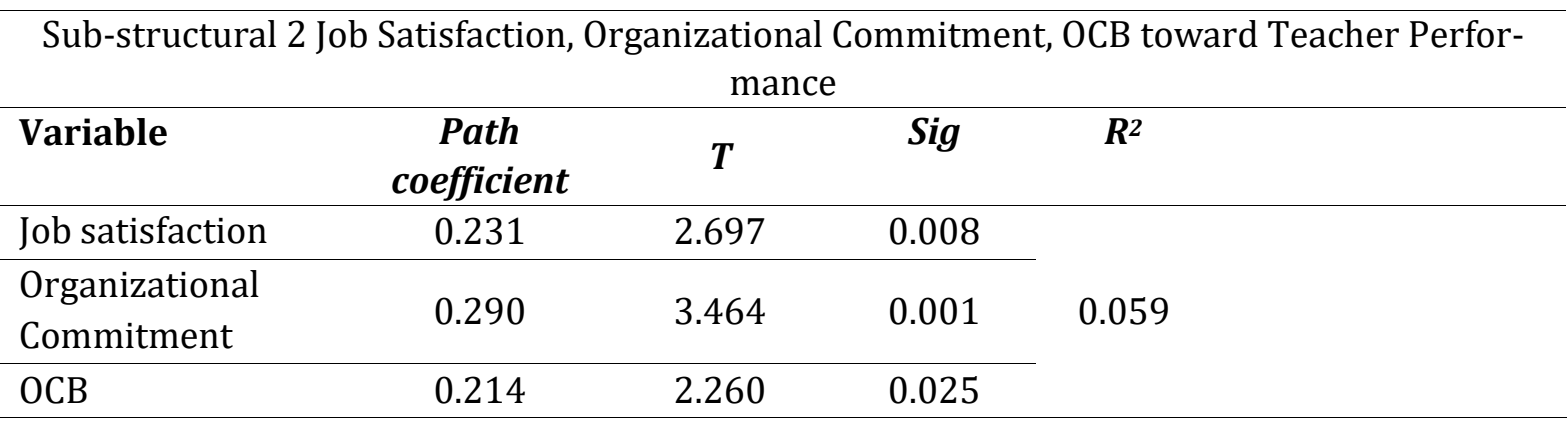

Table 4. Summary of Testing Decisions in Hypotheses H1, H2, H3, H4, and H5

\begin{tabular}{lcc} 
Hypothesis & $\boldsymbol{P}$ & Decision \\
\hline $\begin{array}{l}\text { H1: There is a positive and significant relationship be- } \\
\text { tween job satisfaction and teacher performance }\end{array}$ & 0.008 & Accepted \\
\hline $\begin{array}{l}\text { H2: There is a positive and significant relationship be- } \\
\text { tween organizational commitment and teacher perfor- } \\
\text { mance }\end{array}$ & 0.001 & Accepted \\
\hline $\begin{array}{l}\text { H3: There is a positive and significant relationship be- } \\
\text { tween OCB and teacher performance }\end{array}$ & 0.025 & Accepted \\
$\begin{array}{l}\text { H4: There is a positive and significant relationship be- } \\
\text { tween job satisfaction and OCB }\end{array}$ & 0.000 & Accepted \\
\hline $\begin{array}{l}\mathrm{H}_{5}: \text { There is a positive and significant relationship between } \\
\text { organizational commitment and OCB. }\end{array}$ & 0.000 & Accepted
\end{tabular}

Table 5. Summary of Testing Decisions in Hypotheses H6 and H7

\begin{tabular}{lccc}
\hline \multicolumn{1}{c}{ Hypotheses } & \multicolumn{2}{c}{ Path coefficient } & \multirow{2}{*}{ Decision } \\
\cline { 2 - 3 } & Direct & Indirect & \\
\hline $\begin{array}{l}\text { H6: Job satisfaction toward teacher perfor- } \\
\text { mance through OCB }\end{array}$ & 0.231 & 0.325 & Accepted \\
\hline $\begin{array}{l}\text { H7: Organizational commitment towards } \\
\text { teacher performance through OCB }\end{array}$ & 0.290 & 0.371 & Accepted \\
\hline
\end{tabular}

From the results path analysis table 3 , the correlation between job satisfaction and teacher performance is 0.231 and is positive, there is a relationship between job satisfaction and teacher performance. Mangkunegara (2000) states that the quality and quantity of the performance achieved by human resources is the results in carrying out work duties based on their responsibilities. Job satisfaction is a positive feeling about work, resulting from assessing and evaluating its characteristics. The correlation coefficient between organizational commitment and the performance of teachers from table 3 is 0.290 and is positive, there is a significant relationship between organizational commitment and teacher performance.

According to Robert and Kinicki (2004), organizational commitment is the ability of an employee to recognize and be bound in the organizational goals. This is a critical work attitude since committed workers are expected to show their abilities to work harder in achieving organizational goals and have a greater desire 
to continue working in a company. According to Bano et al. (2019), Because a teacher is a very important human resource from the education sector and its quality is influenced by the level of teacher commitment to school institutions, it is necessary to distinguish to what extent the level of commitment that has been implemented in the field.

The correlation between OCB teachers and the performance of State Vocational High School teachers in Banjar District from table 3 is 0.214 and is positive there is a significant relationship between OCB and teacher performance. The results of this study are in line with Titisari (2014), which stated that these behaviors describe as an added value from employees. This one form of prosocial behavior, including positive, constructive, and helpful social conduct. It is in line with Minarsih (2009), who stated that organizational commitment has a positive and significant effect on OCB. From Robert and Kinicki (2004), organizational commitment is a reflection of an employee to recognize and bind the organizational goals. This is a crucial work attitude since committed employees are expected to show their abilities to work harder in achieving organizational goals and have a greater desire to continue working in a company. Organizational commitment is employee loyalty reflected in high involvement to achieve organizational goals (Priansa, 2014).

The correlation coefficient between job satisfaction and OCB of teachers from table 2 is 0.438 and has a positive, there is a relationship between job satisfaction and OCB. According to Organ et al. (2006), the increase in OCB is influenced by several internal factors of the employees, including job satisfaction, commitment, and personality, employee morale, and motivation. This is in line with Rusminiwati (2015), which stated that there was a positive relationship between organizational commitment and OCB, job satisfaction OCB, and between organizational commitment and teacher satisfaction with OCB. According to Renyut et al. (2017) job satisfaction is a component of organizational commitment in a pleasant condition for someone as a result of conformity between self-values and work. According to Setiawan et al. (2019), there is an indirect relationship between work ethic and OCB through the job satisfaction of teachers of the Banjarmasin City State Senior High School. Teachers try to increase their potential through work ethic, and therefore, they can utilize their abilities through OCB.

The correlation coefficient between organizational commitment and teacher OCB from table 2 is 0.389 and has a positive, there is a positive relationship between organizational commitment and OCB. Tumanggor (2019) also stated that there is a significant positive relationship between OCB and organizational commitment. Additionallty, Luthans (2011) defines organizational commitment as; (a) a strong desire to remain a member of a particular organization, (b) an urge to put efforts at a high level on behalf of the organization, and (c) definite confidence in acceptance of the organization's values and goals.

According to Sopiah (2008) explains that organizational commitment is a unitary attitude of employees. It is the willingness of individuals to strive together with three principal characteristics, including affective, continuance, and normative commitment.

The contribution of job satisfaction to performance through OCB from table 5 is 0.325 , For this reason, there is a relationship between teacher job satisfaction with performance through OCB.

Moreover, the influence between organizational commitment and performance through teacher OCB from table 5 is 0.371 , Therefore, there is a relationship between organizational commitment and teacher performance through OCB. High performance of human resources encourages the emergence of OCB, which is the positive behavior beyond the standard of the company (Robert \& Kinicki, 2004). According to Ehido et al. (2019), The facts that happen is performance are behaviors that are important in their implementation, specifically it is a combined property of various, different Behavior that occurs in a certain period, organizational performance is indicators in The ability of an organization to achieve various resources which are considerably achieved the goal that will be achieved by the organization. 


\section{Conclusion and Recommendation}

The strain $S$. prasinopilosus Pn-TN2 which isolated from termite nest sample, showed a broad range of antimicrobial activity against bacterial and fungal test. Result showed that this isolate possessed inhibition rate antifungal activity by $80 \%$ against $F$. oxysporum, $61 \%$ against $F$. palustris, and $62 \%$ against $T$. viridae. Advised, this isolate also possessed high antibacterial activity against $B$. subtilis, $P$. aeroginosa, and E. coli. Sequence analysis of $16 \mathrm{~S}$ rRNA gene indicated that isolate Pn-TN2 belongs to genus Streptomyces. It shares 99\% similarity with $S$. prasinopilosus. We conclude that termite nest represent source of cultivable Actinomycetes that contribute diverse bio active compounds for further biotechnology application in the medical, pharmaceutical, and agricultural fields.

\section{Acknowledgment}

Job satisfaction, organizational commitment, OCB, and the performance of State Vocational High School teachers in Banjar District are in the high classification. There is an influence between job satisfaction, organizational commitment, and OCB with teacher performance. Additionally, there is a direct relationship between job satisfaction and organizational commitment to OCB teachers. There is also an indirect relationship between job satisfaction and organizational commitment of teachers through OCB on performance. Several suggestions were given to Vocational High School teachers on how to improve their job satisfaction in carrying out the duties and responsibilities, the commitment and organizations to the profession, their OCB on positive behavior, and their teacher's performance on quantity and quality of work.

\section{References}

Arikunto, S. (2006). Prosedur penelitian suatu pendekatan praktik. Jakarta: Rineka Cipta.

Arnold, J., \& Randall, R. (2005). Work psychology: Understanding human behavior in the work place, Fifth Edition. London: Plentice Hall.

Aslamiah. (2015). Hubungan Kepemimpinan Transformasional Kepala Sekolah, Kepuasan Kerja, Komitmen Organisai, dan Organizational Citizenship Behavior
(OCB) dengan Kinerja Guru Sekolah Dasar Negeri di Kota Banjarmasin. karya-ilmiah.um.ac.id. Banjarmasin.

Astawa. (2009). Hubungan kepuasan kerja guru dan motivasi kerja guru pada sekolah menengah atas swasta di Negara www.slideshare.net. Retrieved from www.slideshare.net.

Bano, K., Ishrat, A., Mishra, KK. (2019). Factors affecting organizational commitment of teachers in government and private universities. International Journal of Scientific \& Technology Researc. 8, (11), 138-152.

Chamundeswari. (2013). Job satisfaction and performance of school teachers. International Journal of Academic Research in Business and Social Science, 3, (5), 420-428.

Effendy, M. (2016). Revitalisasi pendidikan vokasi kementerian pendidikan dan kebudayaan. Jakarta: Kemdikbud.

Ehido A., Halim, B. A., \& Awang, Z. (2019). The influence of Quality of Work Life (QWL) and organizational commitment on job performance among academics in the Malaysian public universities. International Journal of Humanities and Social Science Research, 5, (5), 71-76.

Hanif. (2004). Analisis dan perencanaan sistem informasi: Untuk keunggulan bersaing perusahaan dan organisasi modern. Yogyakarta: Andioffset.

Kompri. (2016). Manajemen pendidikan: komponen-komponen elementer kemajuan sekolah. Yogyakarta: Arruzz Media.

Luthans, F. (2006). Perilaku organisasi. Diterjemahkan oleh Vivian A Yuwono dkk. Edisi pertama. Yogyakarta: Penerbit ANDI.

Luthans, F. (2011). Perilaku organisasi. Diterjemahkan oleh Vivian A Yuwono dkk. Edisi pertama. Yogyakarta: Penerbit ANDI.

Mangkunegara, A. P. ( 2000). Manajemen sumber daya manusia perusahaan. Bandung: Remaja Rosda Karya.

Minarsih. (2009). Kontribusi Komitmen Organisasi dan Kepuasan Kerja Guru terhadap Organizational Citizenship Behavior di SMP Negeri Kecamatan Hulu Sungai Utara. Tesis Fakultas Pascasarjana Universitas Lambung Mangkurat.

Organ, D. W., \& Bateman, T. S. (1983). Job satisfaction and the good soldier: The relationship between affect and employee "Citizenship". Academy of Management Journal, 26, 258-595. doi:10.2307/255908. 
Organ, D., \& Ryan. (2006). Organizational citizenship behavior. Its nature, antecendents, and consequences. California: Sage Publications, Inc.

Priansa. (2014). Pengaruh Kompensasi terhadap Kinerja Karyawan pada PT. Pos Indonesia (Persero) Kantor Cabang Bangkalan. Universitas Trunojoyo Madura.

Renyut, B. C., Modding, H. B., Bima, J., \& Sukmawati. (2017). The effect of organizational commitment, competence on job satisfaction and employees performance in Maluku goverrnor's office. IOSR Journal of Business and Management (IOSR-JBM), 19(11), 1829. DOI: $10.9790 / 487 \mathrm{X}-1911031829$.

Robbins, S. P. (2008). Perilaku organisasi: Konsep, kontroversi, aplikasi. Edisi kesepuluh. Jakarta: Prehalindo.

Robbins, S., \& Judge, T. A. (2009). Organizational behavior. 13th Edition. New Jersey: Pearson Education, Inc. Upper Saddle River.

Robert, K., \& Kinicki, A. (2004). Perilaku organisasi edisi 6. Jakarta: Salemba Empat.

Rusminiwati, (2015). Kontribusi Komitmen Organisasi dan Kepuasan Kerja Guru terhadap Organizational Citizenship Behavior di SMP Negeri Kecamatan Tanjung Kabupaten Tabalong. Tesis Fakultas Pascasarjana Universitas Lambung Mangkurat.
Setiawan, T. B., Sulaiman, \& Metroyadi. (2019). Kepuasan kerja sebagai perantara hubungan etos kerja, komitmen kerja dan OCB guru SMAN. Journal of K6, Educatioan, and Management (j-k6EM), 2, (1), 1-7.

Sopiah. (2008). Perilaku organisasi. Yogyakarta: Andi Offset.

Sugiyono. (2012). Metode penelitian pendidikan (Pendekatan Kuantitatif, Kualitatif dan R\&D). Bandung: Alfabeta.

Suparlan. (2006). Guru sebagai profesi. Bandung: Alfa Beta.

Suriansyah, A. (2018). Kepuasan kerja guru di sekolah dasar: hubungan dengan lingkungan belajar. The Open Psychology Journal, 2(1), 1-9.

Titisari, P. (2014). Peranan organizational citizenship behavior (OCB) dalam meningkatkan kinerja karyawan. Jakarta: Mitra Wacana Media.

Tumanggor. (2019). Pengaruh kepuasan kerja dan komitmen kerja terhadap kinerja guru yang di mediasi oleh OCB pada MIN di Kota Banda Aceh. Electronic Thesis and Dissertations UNSYIAH. Banda Aceh: Universitas Syiah Kuala. 